Revista Signos

$2010 / 43$

Número Especial

Monográfico $\mathrm{N}^{\circ} 1$

227-248

\title{
Genre, media, and communicating to learn in the disciplines: Vygotsky developmental theory and North American genre theory
}

\author{
David Russell \\ lowa State University \\ Estados Unidos
}

\author{
Patricia Harms \\ University of North Carolina, Chapel Hill \\ Estados Unidos
}

\begin{abstract}
What is the relationship between medium and genre in learning and development? North American genre theory suggests following Miller $(1984,1994)$ that genre is social action. Genres evoke expectations, direct attention, guide action and suggest 'what motives we may have.' Yet the relationship between media and genres, as Miller suggested at SIGET IV (1997), is complex. The blog, for example, quickly evolved from being one genre to many genres and, today, might be said to be a medium more than a genre. Bazerman at SIGET IV (2007) argued, following Vygotsky (1997), that genres -particularly written genres- 'provide highly differentiated, scaffolded communicative spaces in which we learn the cognitive practices of specialized domains.' This paper provides some evidence for Bazerman's theory from a case study of students in engineering. It shows how genres may scaffold development by directing attention and focusing motivation to ensembles of genres in a range of media, and repay greater study.
\end{abstract}

Key Words: Genre, media, engineering education, writing-to-learn, writing across the curriculum.

Recibido: 20-XI-2009 Aceptado: 24-V-2010
Correspondecia: David Russell (drrussel@iastate.edu). English Department, lowa State University. Ames, IA 50011, Estados Unidos. 


\section{0 gênero, a mídia e o comunicar para aprender nas disciplinas: A teoria desenvolvimental de Vygotsky e a teoria de gênero norte americana}

Resumo: Qual é a relação que se estabelece entre a mídia e o gênero em termos da aprendizagem e do desenvolvimento cognitivo? A teoria de gênero norte-americana sugere, seguindo Miller (1984, 1994), que o gênero é uma ação social. Os gêneros evocam expectativas, dirigem a atenção, guiam a ação e sugerem "quais podem ser os nossos motivos". No entanto, a relação entre mídia e gênero, como sugeriu Miller no IV SIGET (1997), é complexa. O blog, por exemplo, evoluiu rapidamente, de um gênero passando a ser vários gêneros, e, hoje, pode ser considerado mais uma mídia do que um gênero. Bazerman na IV SIGET (2007) argumentou, a partir de Vygotsky (1997), que os gêneros -particularmente os gêneros escritos- "proveem espaços comunicativos altamente diferenciados, na forma de andaimes, nos quais aprendemos as práticas cognitivas de domínios especializados". 0 presente artigo fornece algumas evidências para a teoria de Bazerman a partir de um estudo de caso de estudantes de engenharia. Ele mostra como os gêneros podem andaimar o desenvolvimento, ao se direcionar a atenção e guiar a motivação para conjuntos de gêneros de uma variedade de mídias, produzindo, em retorno, uma educação mais efetiva.

Palavras-Chave: Gênero, mídia, ensino de engenharia, escrever-para-aprender, escrita através do currículo.

\section{Géneros, medios, y comunicación para aprender en las disciplinas: La teoría del desarrollo de Vygotsky y la teoría del género norteamericana}

Resumen: ¿Cuál es la relación entre el medio y el género en el aprendizaje y en el desarrollo? La teoría del género norteamericana sugiere, siguiendo a Miller $(1984,1994)$, que el género es acción social. Los géneros evocan expectativas, dirigen la atención, guían la acción y sugieren qué motivos podemos tener. Sin embargo, la relación entre los medios y los géneros, como lo propuso Miller en la SIGET IV (1997), es compleja. El blog, por ejemplo, se transformó rápidamente de ser un género a muchos géneros y, en la actualidad, se podría decir que es un medio antes que un género. Bazerman, en la SIGET IV (2007) sostenía, siguiendo a Vygotsky (1997), que los géneros -en especial lo géneros escritos- proporcionan espacios comunicativos de andamiaje muy diferenciados en los cuales aprendemos las prácticas cognitivas de dominios especializados. Este trabajo entrega evidencias de la teoría de Bazerman a partir de un estudio de caso en el cual participaron estudiantes de ingeniería. Demuestra cómo los géneros pueden proporcionar andamiaje para el desarrollo al dirigir la atención y centrar la motivación en conjuntos de géneros en un espectro de medios y cómo los géneros pueden prestarse para análisis más profundos.

Palabras Clave: Género, medios de comunicación, educación en las ingenierías, producción escrita para aprender, la producción escrita a través del currículo. 


\section{INTRODUCTION}

In the U.S. there has been for the last thirty-five years an educational reform movement called writing across the curriculum or writing in the disciplines (Bazerman, Little \& Bethel, 2005). There are important similar efforts in Brazil, Colombia, Argentina, and other countries. The idea is to get teachers in all disciplines using writing as a tool of teaching and learning (called 'writing to learn') as well as a way of assessing students. In the last ten years in the U.S. that effort has evolved into communication across the curriculum $(\mathrm{C} \times \mathrm{C})$ or communication in the disciplines (CiD). The goal is to get faculty thinking not only about writing but also about communication in other modes, and the combination of them. For example, at lowa State University there is a CXC program and communications development curriculum called WOVE. It is an acronym for written, oral, visual and electronic communication. There are similar efforts elsewhere, such as the Academic Literacies movement that began in England (Russell, Lea, Parker, Street \& Donahue, 2009). Students must communicate in a range of genres in a range of modes in their courses in their disciplines, and often in other courses.

The central question that is necessary to answer in order to have a principled multimedia communication across the curriculum program is: What is the relationship between medium and genre in learning and development in a discipline? That is the question we will address here in a very preliminary analysis of some data from a case study of a group of students taking courses in two disciplines. The conclusions will also be very preliminary and limited. But perhaps they suggest further lines of theoretical and empirical research.

\section{Theoretical frame}

We assemble several theoretical resources relevant to understanding this problem, though none of which has been specifically applied understanding the relationship between genre and medium in disciplinary learning.

First, there is the recent and growing literature on multimodality in the classroom, including Graham and Whalen (2008), Dannels (2009), Ward (2009), Prior and Shipka's (2009) work (2003), and the work of Kress, especially his studies of secondary school science (2001) and English (2005). This teaches us that, as Kress puts it, multi-modality is the norm (Kress, 2003). Second, North American genre theory suggests, following Miller $(1984,1994)$ that genre can be conceived as social action, "A typified response to a recurring situation" (1984: 163), something that worked once and people have tried again and again successfully. Genres evoke expectations, direct attention, guide action and suggest "what motives we may have" (1984: 163). Yet 
the relationship between media and genres, as Miller suggested at SIGET IV, is complex. 'The nature of genre escapes us when we separate genre and medium,' as Miller put it in her conbribution to Siget IV. The blog, for example, quickly evolved from being one genre to many genres and, today, might be said to be a medium more than a genre. Another significant contribution of North American genre theory is Bazerman's theory of genre systems. In complex activity systems, including those of formal schooling, there are typically many written genres, which participants use together to organize interactions. Bazerman (1994: 80) defines genre systems as "interrelated genres that interact with each other in specific settings". In the synthesis we are developing, we will describe these specific settings as activity systems, which genre systems mediate. In the genre system of some activity system, "only a limited range of genres may appropriately follow upon another" Bazerman (1994: 80), because the conditions for successful actions in each activity system are conditioned -but never finally determined- by their history of previous actions.

Third, the lens of activity theory provides a tool for unpacking the notion of the relationship between medium and genre. In Russell's (1997) synthesis of Bazerman's genre systems theory with activity theory, no medium has priority, and all must be analyzed together. All media can and do provide meditational means (tools in use) for communication and, indeed, all activity. As Spinuzzi (2003) puts it mediation is compound, inevitably multi-modal.

This provides a refinement of the theories that offers us a way to examine closely the motives and values activity systems participants place with certain genres, as well as the role genres play in mediating the activity within and between activity systems. Russell (1997: 504) suggests the synthesized theories can serve as a heuristic for analyzing the "intertextual relations among disciplinary and educational genre systems" and illustrates this tool by analyzing the interaction of the activity systems of the research university and the profession of cell biology through a boundary course: intermediate cell biology. Again, multi-modality is crucial genre systems or ecologies are multi-modal (Spinuzzi, 2003).

Fourth and most importantly, Bazerman at SIGET IV (2009) elaborated Vygotsky's (1997) theory that development follows learning to suggest that genres - particularly written genres- 'provide highly differentiated, scaffolded communicative spaces in which we learn the cognitive practices of specialized domains' (2007). This, he argued, provides a way to understand how writing supports learning. In Vygotsky's theory -unlike Piaget's- learning precedes development. Piaget argued that one must reach a certain cognitive level before one can learn in certain ways, at a certain cognitive level. Vyotsky (1997) turned that on its head.

Tool-mediated semiotic activity transforms cognition by internalizing external cultural tools and 
processes. As we internalize through learning, a cognitive reorganization can take place that Vygotsky (1997) calls development. Accumulated learning 'may' lead to qualitative change: reformulated functional cognitive systems. In Vygotsky's famous example, children at about two years old imitate the speech of others in a babbling that Piaget dismissed as "egocentric" speech awaiting a developmental shift. Vygotsky (1997) theorized this 'egocentric speech' as learning that became, in time, internalized to produce a qualitatively different use of the learning as a tool of self-regulation around age 3. Children learn to talk to themselves out loud, and eventually this talk is internalized as a new stage of cognitive development, conscious thought including planning, self-regulation, and so on.

They provide zones of proximal 'development', as Vygotsky (1997) terms it, not of learning. External cultural tools (e.g., genres) that become internalized have the potential for refiguring prior engagements with the material and social worlds. Bazerman (2009) argued that genres as are important to this qualitative shift from accumulated learning to cognitive refiguration or development. External tools, such as genres, that students internalize have the potential to refigure engagement with the world. One sees the world differently. One sees prior learning differently. Bazerman's (2009) example is grammar. We all study grammar. We learn rules, we learn parts of speech, we learn diagrams of sentences perhaps. But for most people all of that is just learning, often quickly forgotten or, if remembered, not integrated into regular activity. But for many people -certainly all language teachers - that accumulated learning comes to transform the way we think about communication, at some point. We think in terms of this developed and, for us, developmental understanding of grammar; we use it to change the way we write, to evaluate the way people speak and write in different ways, to manipulate language in new ways, to generate new problems, and so on. We begin in other words to have a disciplined understanding that it allows us to see the world in new ways, through the lens of grammar. We become, in effect, specialized. Bazerman (2009: 290) describes this process as "punctuated periods of marked development where the learnings become integrated with other existing or parallel developed functional systems to create new functional systems."

The present study provides some evidence for Bazerman's (2009) theory from a case study of students in engineering. But it goes further to suggest that written genres (or indeed genres in any one medium) may be limited in their capacity to support the cognitive change from quantitative accumulation of facts, data, information and other discrete learning characteristic of general schooling to the qualitative development of disciplinary understanding that genres, Bazerman (2009) theorizes, support and enable. Our case study suggests how genres may scaffold development by directing attention and focusing motivation to 'ensembles' of genres in a range of media, which bring cognitive learning to the point of cognitive development in, identifica- 
tion with, and authoritative production in some specialized field of knowledge and activity.

\section{Methods}

The case study we present is of first year undergraduate (first cycle) engineering students who were simultaneously enrolled in a general writing skills course that almost all first-year students take in American universities and in an engineering design course. We call these 'linked' courses. On many U.S. campuses, faculty and administrators have implemented linked courses, as a strategy designed to foster a coherent first-year experience for students (Ward, 2009). Linked courses are usually separate courses from different disciplines that feature a common cohort of students, teachers who collaborate on syllabi, and assignments that are in some way related to an overarching theme tying the two (sometimes three) courses together. Within the linked course model, a common strategy is linking a required general education course (e.g., first-year general skills writing course) with a professional studies course (e.g., introduction to engineering graphics and design). In the linked course -called a learning community at lowa State University- featured in this study, first-year writing was linked with engineering graphics and design in an effort to help students make meaningful connections between the writing in their writing course and the writing in their engineering course (Harms, Mickelson \& Brumm, 2001; Mickelson, Harms \& Brumm, 2007).

The study was conducted at a large research institution in the U.S. Midwest and featured a learning community designed for first-year agriculture and biosystems engineering ( $A B E)$ students. The ABE Learning Community was selected as the research site because it was a bellwether case for studying interdisciplinary connections. Not only did the learning community feature a linked first-year writing course (general education course) linked with a professional studies course (a common learning community configuration), the learning community was a well-respected and successful learning community.

This research was conducted in the department of Agricultural and Biosystems Engineering (ABE) (Harms, 2003). Specifically, the formal sites for this research were two linked courses: first-year writing (English 104, which included a traditional classroom and computer lab) and introduction to engineering graphics and design (Engineering 170, which included a traditional classroom, a computer lab, and a mechatronics lab (where students worked on a robot project). Both English 104 and Engineering 170 are three credit courses (each about 1/10 of a student's yearly program): English 104 met two times per week for 80 minute sessions, while Engineering 170 met up to four times per week for lecture, group work-time, and lab time. Harms also gathered data by spending time in the ABE department. 
The demographics of the group are representative of the general profile of students at the university who select agricultural and biosystems engineering ${ }^{1}$. All of the students in the study were 18-19 year-old white males; eight were from rural lowa and one was from rural Illinois. Not only were the all students from rural communities, they were all intimately familiar with agriculture and had extensive experience with farming. Additionally, all of the students were enrolled in English 104 due to ACT scores that were lower than the official cut-off score (24) used to advance place students into First-Year Writing II (English 105) during the 2000-2001 academic year. We have given the students pseudonyms. Data collection over 20 weeks included observations (in-class and informal hall and lounge talk), interviews (most discourse-based), and text analysis (complete methods are in Harms, 2003). Data were gathered under the auspices of the Institutional Review Board of lowa State University.

Data consisted of observations of linked courses ( 27 hours); four focus groups with six students ( 3 in $1^{\text {st }}$ term, 1 in $2^{\text {nd }}$ term); individual interviews (2) with the six students and the two teachers (4). Data was analyzed qualitatively by identifying themes (Miles \& Huberman, 1994).

The first research question was: Where did students show evidence of connections/disconnects between courses? A re-analysis of data after rethinking the results in light of Bazerman's theory was guided by the question, Is there any evidence of cognitive shifts of the type Bazerman described?

\section{Results/discussion}

In the learning community, the linked courses were selected and designed to help students overcome the perception that first-year writing is an encapsulated activity unrelated to the engineering curriculum and to foster an environment in which the students were encouraged to make useful or meaningful connections between the disciplines of writing and engineering. The first two thirds of the course was designed to have them write about agriculture and engineering, presumably what they knew best. Unit 1 was titled 'Who are you? Where do you come from? What does it mean to be at the university?' Unit 2 was titled 'Where are you going? What do you want to become?' They wrote about their farming backgrounds and their future career in engineering. But significantly, as it turned out, they wrote genres that were, with one exception, from English: a personal narrative paper on identity, a future career plan, and a dream resume (see Figure 1). 


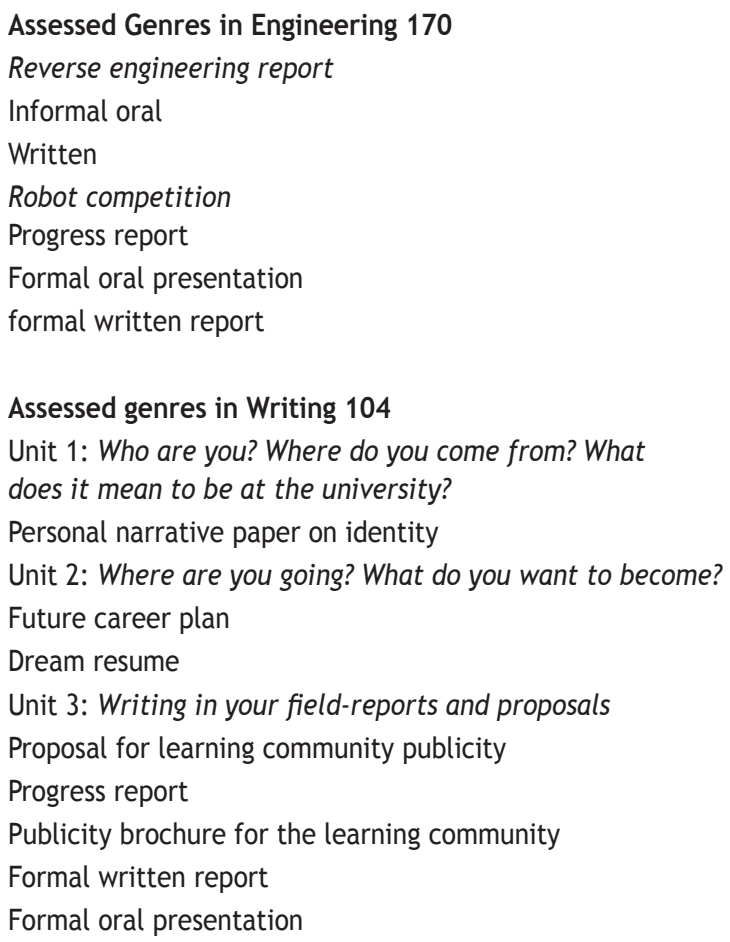

Figure 1. Assessed genres by project or unit.

In the third and final unit of the course, they did not write about engineering or farming. Instead they wrote about their writing course. They did a project to publicize the ABE learning community program on campus. However, the students recognized those genres as being 'technical'. They wrote a proposal, a progress report, brochure, and group presentation recruiting for the learning community (Figure 2). 


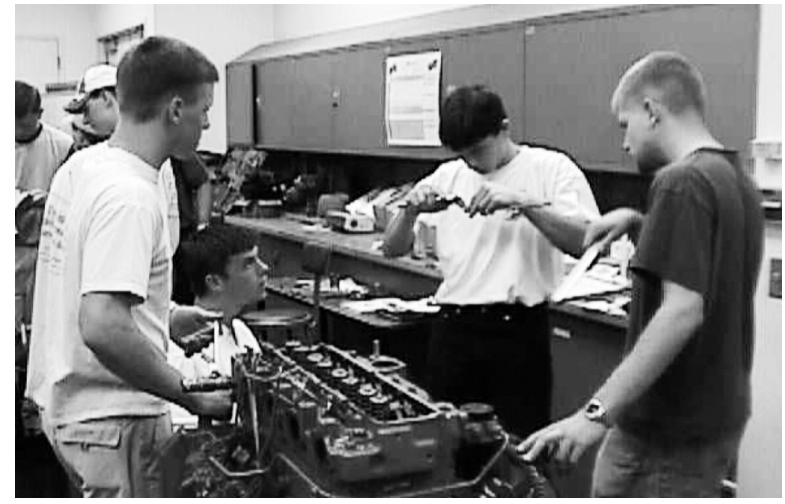

Figure 2. Oral communication around mechanical tools.

Yet, according to the student research participants, they only perceived connections between the courses when they perceived the information learned in English as being useful to their courses in engineering. This perception of the importance of English being useful to engineering and not the reverse provides evidence of the students desire to move toward engineering and not university schooling in general. It also suggests the students are beginning to take on the identity of engineers, i.e., 'From the perspective of an engineer, why is this information useful to me?'

Importantly (and by design) the genres of the Engineering 170 course echoed those of the final third of the English course (see Figure 1). The students did a 'reverse engineering' team project in which they took apart and reassembled a tractor engine, then did a team oral and written report. The second project was a robot competition, in which the students in teams designed, built, and competed with robots. They also completed formal oral and written reports, in stages.

An activity theory analysis (Russell 1997; Russell \& Yánez, 2003) helps explain why the students were motivated to engage in certain genres but not others assigned in their first-year writing class. In this case, the students were motivated to engage with those genres they perceived as being related to engineering, but not those genres they perceived as being related to general schooling. Importantly, when the students were motivated by the 'engineering' genres, they were motivated to engage in their first-year writing course in important new ways. The focus on agriculture and on their future as engineers in the first two thirds of the English course seemed irrelevant. Students perceived some connections in the last third. It was the genres of 
'technical writing,' as they expressed it, which provided the link between the courses. This occurred in spite of the fact that the content of the final unit had nothing to do with engineering content, as a publicity plan for the learning community. The students spoke and wrote of this perception in terms of a 'split in the class.' According to the students, the first two-thirds (they called it half) of the course was more 'like a regular English class' while the final third of the course was 'truly a learning community course.' Similar genres, not similar content, are what the students perceived as linking the courses. As one student put it, 'I really enjoyed this [last] half of class. It did seem like a totally different course.' The content does not t have to be that of the field the students are interested in, as long as they perceive the genres as being potentially part of their future (identity) (Rice, 2009). The students did not respond to the English course when the content was theirs, but only when the genres were 'theirs'.

During the so-called learning community portion of the course, the students were afforded a ZPD through the introduction the genres of technical communication. Allen is one student who wrote about his perception of the split in English 104 in his end of semester reflection for English 104:

"I noticed at about midterm or a little earlier you changed the course of the class. It truly became a learning community with engineering 170 . Since you did that it has been a very beneficial class. The stuff that we were learning applied to engineering 170 and it was something that we would actually be using in the future" (Allen, English 104 end-ofsemester reflection, December, 2000).

According to the student, the course was split into two halves. Later during a discourse-based interview, Allen was asked to expand on this passage.

Researcher: Let's look at your 104 stuff... In your reflections to Ms. [Kate], you talked about...at the beginning of the semester it was a typical English class...Can you talk any more about that?

Allen: Well, she started out with just going over essays and stuff, kind of like I'm doing this semester. She'd give us an essay and we'd have to write about that. But then about mid-term or so she started changing it and we actually did stuff that was relevant to 170 . We'd actually write papers about that instead of just writing papers about essays out of the book that really had no relevance to us as engineering students...It started out kind of boring like a usual English class but then we started getting into stuff we're actually working with and it made it a lot more interesting. And I was willing to get more in-depth with it because I could see how it was going to be applied...You could see how you would use it in the future, so I was willing to learn more from it.

Significantly, Allen pointed to several important issues. First, apparently he (and perhaps the other students) perceived the first two-thirds of English 104 to be a 'regular' English course 
because he perceived it to lack relevance to engineering, even though the content was explicitly about the students backgrounds in agriculture and future careers in Engineering. Secondly, Allen identified that 'getting into stuff we're actually working with' was important to him because it made the course 'more interesting.' While Allen didn't say so specifically in this passage, the students unanimously reported that the second half of the course occurred when the instructor, Kate, began asking them to write genres typically recognized as technical communication (e.g., proposals, reports, memos). Allen also noted that he was 'willing to learn more from it' when he recognized the material being taught in English 104 as being relevant to engineering. When the students began to perceive the first-year writing course as 'truly a learning community course,' they were able begin to resolve their perceptions of boundaries between their linked courses and to see the courses as new, complementary systems of activity. Interestingly, the students did not question the 'new' direction of the first-year writing course; rather, they welcomed the change.

\subsection{Cognitive refiguration: Retrospectively reorganized cognition}

Both the engineering professor teaching the Engineering design course and the students perceived that their performance was better than the students who were not in the learning community, and the students attributed that to the experience of doing 'technical writing' in their English course, and to the genres. As one student put it, "I guess that was one of the [similar] things that we noticed... [were] the memos [proposal \& report]. The memos needed to be written like the stuff in 170 even though it was for an English class.' Bruce, the student who was cited previously as saying that he enjoyed the half of the class that included proposal writing. In the English 104 end-of-semester reflection cited below, Bruce wrote that he felt that the technical communication assignments were valuable to the writing he had also done in Engineering 170 and that having familiarity with the genres enabled him to perform at a higher level in the class than other students performed. Bruce also indicated that he believed the genres would be useful to him in the future:

First of all, the biggest ${ }^{2}$ paper that we have written in this class is the proposal, progress report and presentation. I can already say that this has come to be a huge asset....with engineering 170 . We did a similar situation in 170 as a group. In my group was Don [another 104 student] and we can both speak up and say we were farther ahead than the other students, who were both sophomores and not in your class. I know that if this one project has come into play already that it will again in the near future. I enjoyed this project a lot (Bruce, English 104 end-of-semester reflection, December, 2000). 
In this reflection, Bruce noted that the technical communication project, or as we have labeled it, the genres, would likely be useful to him 'again in the near future.' This statement suggests that Bruce had appropriated the genres because he had found it useful once and he believed it would be useful again.

Yet another student who wrote about the usefulness of the genres was Gary, the student who was the most vocal about the unfairness of the ABE learning community section of English 104 being different from other sections of the same course. Despite expressing deep frustration with English 104 all semester, Gary wrote positively about the genres in his end-of-semester reflection. In the following end-of-semester reflection, Gary noted that he perceived the genres as worthwhile, i.e., useful, and that he believed he would be doing similar types of writing in his professional future.

I think doing this unit was very worthwhile. I will almost certainly write proposals and progress reports in my future career. I learned the format for proposals and for progress reports (Gary, English 104 end-of-semester reflection, December, 2000).

Significantly, all of the students cited in the examples above recognized the genres as being similar to the genres they were writing in their engineering course. Perceiving the genres as belonging to something different than the genre system they had attached to schooling allowed the students to assign new meaning and new value to the genres. By perceiving the genres as belonging to engineering and not English, the students saw them as having greater social value than other genres they had been writing in their writing course, i.e., social value in the activity system of engineering that they were hoping to join.

According to the Engineering professor, the learning community students 'got it' faster. They were 'thinking more like engineers.' Indeed, the learning community students saw 'English' in a different light -as something that engineers do, which was a goal of the learning community link.

Accordingly, we began to re-analyze the data to ask what it was about the genres of the final unit in the course that so struck them (and their Engineering professor) as useful? What did the genres in the two courses have in common, beyond the names (progress report, report and presentation)? Our analysis suggested two things.

\subsection{Ensembles of genres in various media in the genre ecology of the course}

The genres of the final third of the English course did indeed share conventions with the genres the students wrote in their engineering design course that semester (and did not share them with the genres they wrote in the first two thirds of the English course). And it struck us that 
those conventions were precisely those that integrated modes: images the students themselves created, data tables, graphs from data, visuals integrated with text, oral presentations with rich graphics -genres that had a clear structure pre-organized to link visual and oral elements to written ones. The English 104 documents did resemble the students' engineering documents in form. For one thing, all of the documents in the group required the students to use headings. In addition, the brochure assignment required them to use visuals in a document written for their English class. They had also been required to use visuals in the writing they were doing for their engineering class. The form of the documents fostered the perception that these English 104 genres belonged to the genre system of engineering.

We suggest here that within the broader system or ecology of genre in a discipline or educational program (curriculum) or even within a classroom typical of the discipline there are characteristic genre ensembles that are recognized, and that these tend to be multimodal. In this case, the ensemble recognized by the students involved a proposal and report, oral and written (also a fundamental triad of genres in the engineering as well as other disciplines of course). The Slavic folklorist Pope (1977: 673) describes a work that incorporates many small genres as "a distinct genre-ensemble made up of a number of mini-genres." This is reminiscent of the terms pluri-genre or hybrid genre, but it is combinations of genres that have become regularized, operationalized through repeated use so that they do not represent a break with previous genres, a disconcerting mélange, but rather an ensemble in the musical sense, a conventional combination of different instruments or voices. Neither is an ensemble of genres Bakhtin's (1986) 'secondary genre' per se, though it does combine oral and written genres, as well as other multi-modal combinations. For Bakhtin (1986) has in mind larger structures such as the novel, and a genre ensemble orchestrates various genres in concert within a genre system (such as proposal and report) rather than incorporating them into one (e.g., the novel). Moreover, a genre ensemble is an analytic category primarily concerned with production rather than, as with secondary genre, reception.

The students show evidence of having retrospectively re-organized cognition, 'cognitive refiguration,' in terms of seeing themselves as engineers and communicating like them through these ensembles of genres. English now made sense in terms of Engineering and Engineering made sense in terms of English. Communication using headings and visuals is part of engineering. And headings and visuals are part of English. In this sense, the students came to view more of their intellectual landscape in terms of what they considered to be engineering. It appears that, as Bazerman's (2009) theory suggests, genres scaffolded students' development as engineers. Knowledge (of farming, of engineering) was a necessary precondition, but it was the genres that gave students the sense of the field, and a sense of themselves as engineers. 
However, the manner in which the genres served as ZPDs seemed to go deeper than the surface features or conventions. The documents the students were writing in English 104 were not functionally related to engineering or agriculture, an important issue that suggests that more than the documents' surface features were at play in the students' recognition of the documents as belonging to an activity system other than schooling.

\subsection{Transfer of dispositions}

When we first analyzed the data we were looking for 'connections between courses,' but connections in a more traditional sense of transfer of learning. That is, we were looking for what Bereiter (1995) called transfer of principles, gaining a depth of understanding that would allow a student to recognize new cases of a general principle and apply them. We found very little evidence of this except, as we noted, that students used some similar conventions of genres and were, in both courses, concerned with the audience of their communication, especially the teacher.

But Bereiter (1995) theorizes another kind of connection, another kind of transfer, a 'transfer of dispositions.' This happens when a student, having been in some learning situation develops the dispositions necessary to engage in similar activity or learning elsewhere. A disposition is to have the tendency to act in a similar way in similar circumstances. A disposition is in essence a temperamental makeup or character trait, but one that can be taught. It can include attitudes toward work practices (Bereiter, 1995). Boscolo and Mason (2001) used the theory to study transfer of writing to learn between disciplines, specifically the transfer of the 'disposition to engage in meaningful writing' from history to science. Something similar seems to have happened in the learning community study.

The technical communication genres the students wrote in English 104 likely afforded the students their first opportunity to use multi-modal to do meaningful work beyond the activity system of schooling, i.e., writing that was a means to an end (engineering) and not an end in and of itself in the activity system of schooling (course grade). They did classroom writing that had, in Engeström's (1987) terms, use-value as well as exchange-value. Writing that not only helped them make grades, but writing that also helped them to make sense. The distinction between grade-maker and sense-maker is used by Engeström (1987) to describe students' process of learning by expanding. The students were moving from an activity system of education in general (students as grade-makers) to the discipline specific activity system of ABE education (students as sense-makers). 
Writing documents typically recognized as belonging to the technical communication genre gave the students an opportunity to practice using writing as discipline-based action, to experience engineering through writing engineering-like documents, which is to say multi-modal documents in a genre ensemble typical of engineering. Berkenkotter and Huckin (1995: 118) suggest student writing is useful as research data because writing serves as a visible index of students' "initiation into an academic discourse community". Learning to write documents the students recognized variously as technical communication and professional writing provided a tangible, visible index of useful learning, i.e., learning that was relevant to engineering occurring in the activity system of English 104, a general education course. What then were those dispositions and how was the production of certain multi-modal genres potentially related to them?

\subsection{The ZPDs around the engine and the Learning Community Publicity Plan}

How did the students come to perceive the similarities, to see the genres as 'technical' and related to engineering? If we look at the two photos (Figures 2 and 3) we see the students are engaged in goal oriented projects in a collaborative and multi-modal way: Taking notes, sketching diagrams, entering and graphing data, rehearsing informally what they will say to the professor, etc. In both courses during the crucial units, the work was focused on specific objects, whether mechanical or discursive, and in both courses the students were assembling materials, discussing them, evaluating them, creating visuals, analyzing data, preparing to orally present, and so on. Prior and Shipka (2003) describe these informal multi-modal/media genres as extremely important, drawing on what Swales terms the hidden or 'occluded genres' that exist in many genre systems.

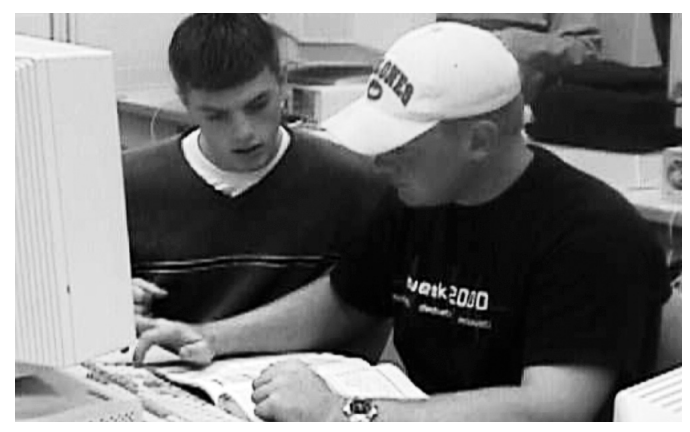

Figure 3. Oral communication around linguistic tools. 
Students in interviews and focus groups repeatedly point to the shift toward this complex activity leading to products, which they describe in terms of it being 'real.' Visuals, tables, and diagrams as well as descriptions were drawn from the students' classroom and lifeworld in both projects. They were integrated with text in certain genres tied to manipulation of apparatus, to design of machines (robots, in this case). They were tied to oral collaboration and formal oral presentation, with deadlines looming. The process of engineering became for them genred in certain multi-modal genre ensembles, and the processes of production of those genres linked to certain dispositions. The genres, moreover, were seen as repeated, not one-off. They would use these ways of working and ways of communicating (both tied together) in the next course too, which was very different in terms of content.

Hans wrote about the technical communication genres in his end-of-semester reflection for English 104. From Hans's perspective, knowing that he was developing a 'real world' product was motivating for him, because he perceived the assignment 'would be applicable to real live situations.' In activity theory terms, Hans could imagine the genres as a tool-in-use:

"The group project that I worked with on the later part of this semester was a very practical way to study English. I really liked how we had to develop a product, like we would in the real world that we knew actually existed. It was concrete. I could see how this assignment and the fruits of its labor would be applicable to real live situations" (Hans, end-of-semester reflection, English 104).

Significantly, Hans suggested that it was the potential action he associated with the technical communication documents as being motivating to him, not the form of the documents. In Hans's words, the students 'develop[ed] a product' that they 'knew actually existed' in 'real live situations.' In other words, the students wrote genres they perceived as relevant to activity systems outside of the general activity system of schooling. In contrast were the early assignments required in English 104. These assignments were similar to the kinds of writing the students had done in secondary school, where writing that had no relevance outside the activity system of schooling from the students' perspectives. Again, the students had such a limited understanding of engineering that only those things that were obviously related to engineering were valued or seen as connected to engineering. But the ensembles of genres in different media seemed to have scaffolded their developing understanding of engineering and involvement and identification with it, and their perception of non-engineering (English) in new ways as well. The form of the technical communication documents as well as the social action of the genres likely helped the students perceive the genres as relevant to engineering, and in that way, the genres helped to coordinate English 104 with engineering 170. The ensembles of multi-modal genres afforded the students a ZPD. 
Interestingly, the students perceived the genres as relevant to the activity system of $A B E$ despite the fact that the genres were not related to their engineering assignments nor were they specifically presented as engineering writing. In Russell's terms (1997), the genres provided an 'intertextual linkage' between the first-year writing classroom and the profession of engineering. This linkage fostered a perception of relevance for the students and, therefore, motivated the students to engage more deeply in their writing course. In short, the genres provided the students textual pathways for their expanding involvement into the activity system of engineering. Later the students demonstrated appropriation of the tool when they reported that the 'technical writing project [from first-year writing] was a huge asset,' and one student went so far as to speculate that having a better understanding of what we have labeled the genre ensembles had enabled the students to perform at a higher level in their engineering class than students who were not familiar with the genres in the other (English) setting.

\section{CONCLUSION: GENRES, MEDIA, AND DEVELOPMENT}

This very preliminary re-analysis of data, as suggested by Bazerman's (2007) theory, has many limitations. In addition to it being a case study with small numbers and only two disciplines involved, it is specifically a 'bellweather' case, designed to create a context where connections were possible. The data draw on is also primarily interview and focus group, rather than observational or experimental. So it is difficult to see in any detail the attentional processes at play in the multi-modal interchanges or even to describe the multi-modal ensembles of genres with any precision. Moreover, it occurred over only two semesters, and it is difficult to see any cognitive reorganization of learning of dispositions, particularly that might be seen as stable over time or generative, as Vygotsky (1997) says developmental shifts are. And we suggest below further research that might tease out these effects if they exist.

Nevertheless, Bazerman's (2007) theory that, following Vygotsky (1997), genres 'provide highly differentiated, scaffolded communicative spaces in which we learn the cognitive practices of specialized domains' is to some degree supported by this case study. Genres appeared to scaffold development by directing attention and focusing motivation -and this in spite of the fact that students were in another course, another discipline. And they did so not when the content was related but when the genres were related.

Carter, Ferzli, and Weibe (2004, 2007) have theorized 'apprenticeship genres' characteristic of each discipline that index the fundamental logic of a discipline (its 'scientific concepts,' in Vygotsky's (1997) term, or Davydov's (2009) 'germ cell'). The technical report is, they argue, the central apprenticeship genre of engineering. But it may also be worth investigating the 
characteristic multi-modal/media practices that realize the genre and cause it to be perceived in certain ways and not others, practices analyzable as systems/ecologies of genres, often 'occluded' ones. And it may also be worth analyzing the particular visual aspects of the dominant or 'apprenticeship' genres. In the technical reports the students wrote for both engineering and English, there were writer-created images, captioned; data summarized in tables and graphs; extensive use of headings, and other visual elements characteristic of the genre. Each of these elements appears in other genres of other disciplines, of course, but it could be argued that they form a particular ensemble in typical ZPDs of engineering education.

It is interesting to note that in many fields there is a central genre that is quite explicitly multimodal, in ways characteristic of the discipline, and which appears at relatively elementary levels of understanding and instruction (in the first course in the discipline taught, at whatever level, including elementary school). In astronomy the model of the solar system or star map, in grammar the sentence diagram, in history the timeline, in experimental science the data table and graph, in chemistry the periodic table of the elements, in mathematics the equation, in geography the map. In each of these, a combination of visual and textual elements directs attention to the essential analytical processes of the discipline. But the characteristic visual/ textual/oral ensembles of genres characteristic of each discipline also index and often organize the activity of students and practitioners in these fields, at various levels, and perhaps scaffold the communicative dispositions necessary.

The effects of writing (or other media of production) on cognition are hard to tease out because they take place over time and are embedded so deeply into various practices (Markel, 2009). The same is true of what has been called 'transfer' of knowledge, cognitive skills, training, and so on. This case suggests to us that the two might be related in this. That writing to learn and 'transfer' are really 'transformational' rather than transfer (Tuomi-Grohn, Engeström \& Young, 2003), transfer of dispositions as well as transfer of principles (Bereiter, 1995). Cognition is transformed gradually (though with important and recognizable qualitative shifts, as Bazerman (2007) has pointed out) but so is the disposition toward learning and communicating in a certain field that accompanies it. And genre, conceived in terms of social action, of activity systems or ecologies, may be helpful to understanding both, at the level of activity, at the level of action, and at the level of operations or habits.

Further research into the relationship between genre and medium in learning and development might consider in greater depth some of the issues raised by this preliminary study. Are there ensembles of genres (in various media) that are associated with, not only learning, but also social/cognitive development in a field? How can such ensembles be described and analyzed? How are they structured and how do they function within specific contexts? In this, the theo- 
retical concept of 'conscience disciplinaire,' or disciplinary consciousness may be of help, as it seeks to describe the manner in which students construct the academic disciplines, over the course of their development form pre-school through professional formation (Reuter, 2007). Carter (2007) has suggested that there are 'meta-genres' that extend across disciplines. This research might reveal the 'mini-genres' or occluded genres that work together to scaffold the qualitative shift from accumulated learnings to qualitative shifts in development. In particular, the new versions of process tracing pioneered by Prior and his group might tease out the microprocesses, or 'laminated' activity, in his term, that accompanies such cognitive reorganization in students who make that shift (and that doesn't in those who don't). Similarly, longitudinal studies might provide longer-term evidence of the role of genre and media in such shifts, by looking at the curriculum and instruction in a particular field and following students through it. And it is possible to imagine quasi-experimental studies of students in an online curriculum where there are interventions to deliberately emphasize and make visible the multi-modal genres and ensembles of genres in areas where then can be identified and analyzed. Clearly, collaboration with experts in didactics and pedagogy of other disciplines will be necessary, as well as considerable theoretical and methodological work to understand the role of genre and media in learning and development from a Vygotskian point of view.

\section{REFERENCES}

Bakhtin, M. (1986). The problem of speech genres. In C. Emerson \& M. Holquist (Eds.), Speech Genres and Other Late Essays (60-102). Austin: University of Texas Press.

Bazerman, C. (1994). Systems of genres and the enactment of social intentions. Genre and the new rhetoric, 79-101.

Bazerman, C. (2007). Genre and cognitive development: Beyond writing to learn. SIGET [on line]. Retrieved from: http://www3.unisul.br/paginas/ensino/pos/linguagem/cd/ English/5i.pdf.

Bazerman, C. (2009). Genre and cognitive development: Beyond writing to learn. Genre in a Changing World, Perspectives on writing (pp. 279-294). Fort Collins, CO: The WAC Clearinghouse.

Bazerman, C., Little, J. \& Bethel, L. (2005). Reference guide to writing across the curriculum [on line]. Retrieved from: http://wac.colostate.edu/books/bazerman_wac/

Bereiter, C. (1995). A dispositional view of transfer. Teaching for transfer: Fostering generalization in learning, 21-34.

Berkenkotter, C. \& Huckin, T. (1995). Genre knowledge in disciplinary communication: Cognition/culture/power. Hillsdale, N.J.: L. Erlbaum Associates. 
Boscolo, P. \& Mason, L. (2001). Writing to learn, writing to transfer. Studies in writing, 7, 83104.

Carter, M. (2007). Ways of knowing, doing, and writing in the disciplines. College Composition and Communication, 58(3), 385-406.

Carter, M., Ferzli, M. \& Wiebe, E. (2004). Teaching genre to English first-language adults: A study of the laboratory report. Research in the Teaching of English, 395-419.

Carter, M., Ferzli, M. \& Wiebe, E. (2007). Writing to learn by learning to write in the disciplines. Journal of Business and Technical Communication, 21(3), 278.

Dannels, D. (2009). Features of success in engineering design dresentations: A call for relational genre knowledge. Journal of Business and Technical Communication, 23(4), 399-427.

Davydov, V. (1990). Types of generalization in instruction: Logical and psychological problems in the structuring of School Curricula. Soviet studies in mathematics education. Volume 2. National Council of Teachers of Mathematics, VA.

Engeström, Y. (1987). Learning by expanding: An activity-theoretical approach to development research. Helsinki: Orienta-Konsultit.

Graham, S. S. \& Whalen, B. (2008). Mode, medium, and genre: A case study of decisions in NewMedia design. Journal of Business and Technical Communication, 22(1), 65-91.

Harms, P. L. (2003). Writing-Across-the-Curriculum in a Linked Course Model for First-Year Students: An Activity Theory Analysis. Unpublished Dissertation, lowa State University, USA.

Harms, P., Mickelson, S. \& Brumm, T. (2001). Using learning community course links to bring meaning to the first-year engineering curriculum. Proceedings of the 2001 American Society for Engineering Education Annual Conference \& Exposition, Albuquerque, NM, Session 1653.

Kress, G. (2001). Multimodal teaching and learning: The rhetorics of the science classroom. Advances in applied linguistics. London; New York: Continuum.

Kress, G. (2003). Literacy in the New Media Age. Literacies. London: Routledge.

Kress, G. (2005). English in urban classrooms: A multimodal perspective on teaching and learning. London; New York, NY: RoutledgeFalmer.

Markel, M. (2009). Time and exigence in temporal genres. Journal of Business and Technical Communication, 23(1), 3-27.

Mickelson, S., Harms, P. \& Brumm, T. (2007). Longitudinal study of learning communities in agricultural and biosystems engineering. International Journal of Engineering Education, 23(4), 672-682.

Miles, M. \& Huberman, A. (1994). Qualitative data analysis: An expanded sourcebook. SAGE publications, Inc. 
Miller, C. (1984). Genre as social action. Quarterly Journal of Speech, 70, 157-78.

Miller, C. (1994). Rhetorical community: The cultural basis of genre. Genre and the new rhetoric, 67-78.

Pope, R. (1977). Review: But the literature does not fit the theory: A critique of the teleological approach to literature. Slavic Review, 36(4), 667-675.

Prior, P. \& Shipka, J. (2003). Chronotopic lamination: Tracing the contours of literate activity. In C. Bazerman \& D. Russell (Eds.), Writing selves, writing societies: Research from activity perspectives (pp. 180-238). Fort Collins, CO: The WAC Clearinghouse.

Reuter, Y. (2007). La conscience disciplinaire: Présentation d'un concept. Education et didactique, 2(1), 1-15.

Rice, J. (2009). Networked exchanges, identity, writing. Journal of business and technical communication, 23(3), 294-317.

Russell, D. (1997). Rethinking genre in school and society: An activity Theory Analysis. Written Communication, 14(4), 504-54.

Russell, D. \& Yáñez, A. (2003). Big picture people rarely become historians: Genre systems and the contradictions of general education [on line]. Retrieved from: http://wac.colostate. edu/books/selves_societies/

Russell, D., Lea, M., Parker, J., Street, B. \& Donahue, T. (2009). Exploring notions of genre in "academic literacies" and "writing across the curriculum": Approaches across countries and contexts. In C. Bazerman, A. Bonini \& D. Figueiredo (Eds.), Genre in a Changing World (pp. 395-423). Fort Collins, Colo.: WAC Clearinghouse.

Shipka, J. (2009). Negotiating Rhetorical, Material, Methodological, and Technological Difference: Evaluating Multimodal Designs. College Composition and Communication, 24.

Spinuzzi, C. (2003). Tracing genres through organizations: A sociocultural approach to information design. Cambridge, Mass.: MIT Press.

Tuomi-Grohn, T., Engestrom, Y. \& Young, M. (2003). From transfer to boundary-crossing between school and work as a tool for developing vocational education: An introduction. In T. Tuomi-Grohn \& Y. Engeström (Eds.), Between School and Work: New Perspectives on Transfer and Boundary-crossing (pp. 1-15). Amsterdam, Netherlands: Pergamon.

Vygotsky, L. (1997). The collected works of L.S. Vygotsky: The history of the development of higher mental functions. New York: Plenum.

Ward, M. (2009). Squaring the learning circle: Cross-classroom collaborations and the impact of audience on student outcomes in professional writing. Journal of Business and Technical Communication, 23(1), 61-82. 


\section{NOTES}

1 The ABE department actively recruits underrepresented students and is in the process of adding a new biosystems engineering degree that will likely attract a broader audience; nevertheless, the learning community for the 2000-2001 academic year included only white males.

2 The student is using the word biggest to mean de best. Later in his reflection, he states, "The second best part of this 104 class..." 